\title{
THE PRACTICAL IMPORTANCE OF THE SINGLE ARTERY UMBILICAL CORD
}

\author{
RICHARD F. HNAT* \\ Department of Obstetrics and Gynecology, \\ The New York Hospital-Cornell Medical Center, New York
}

(Received 23rd May 1966)

\begin{abstract}
Summary. The correlation of single artery umbilical cords with congenital anomalies is explored in the present study of 4808 consecutive deliveries. There were thirty-eight single artery cords, and six of these were associated with additional foetal abnormalities. An attempt is made to present the correlation in a true perspective by adding these data to other similar studies. Acknowledgment is given to the many retrospective studies, but consecutive delivery series show that a single artery cord is of importance as an abnormal physical finding but not as a screening test to detect occult malformations.
\end{abstract}

\section{INTRODUCTION}

Recent studies from large obstetrical services have suggested a correlation between the absence of one umbilical artery and congenital anomalies.

Although this association had been mentioned before and after the observation attributed to Hyrtl, it attracted little attention until the work of Benirschke \& Brown (1955), a retrospective study of fifty-five placentae and autopsies of newborns from three different institutions. Of these infants, twenty-seven exhibited malformations involving all organ systems. Since 1955 many reports have appeared. Retrospective studies have taken the form of either autopsy material or accumulated cases, usually from different hospitals, added to the experience of the large teaching institution from which the report emanated (Table 1). Prospective studies consist entirely of cord specimens collected from consecutive deliveries, and they have consequently suffered from the small number of cases (Table 2).

In both types of study, multiple maternal, foetal and placental factors were correlated with the presence of a single artery umbilical cord. Benirschke again provided the most comprehensive evaluation, but other authors have also stressed some interesting points.

(1) Maternal: Age, parity and heredity have been investigated with such varying results that no significance can be assigned to any of these factors.

Some studies have suggested that maternal disease is an important factor. Initially, pre-eclampsia was manifested in $30 \%$ of the cases collected by Benirshcke \& Brown (1955). Later work of Benirschke \& Bourne (1960) found the

* Present address: 59 Franklin Street, Morristown, New Jersey. 
incidence to be $9 \%$, and then $16 \%$ (Bourne \& Benirschke, 1960). The first observation of $30 \%$ has been attributed to a selection bias, and no other author has ever confirmed this finding.

Hydramnios was noted in 8 to $19 \%$ of Benirschke's cases. In one series, he found that all nineteen infants associated with both hydramnios and a single artery cord had anomalies. Again, other studies failed to support this finding.

TABLE 1

RETROSPECTIVE STUDIES

\begin{tabular}{|c|c|c|c|c|}
\hline \multirow{2}{*}{ Author } & \multirow{2}{*}{ Material } & \multicolumn{2}{|c|}{$\begin{array}{c}\text { Anomalous } \\
\text { infants }\end{array} \mid \begin{array}{c}\text { Single artery } \\
\text { cords }\end{array}$} & \multirow{2}{*}{ Type } \\
\hline & & No. & $\%$ & \\
\hline Benirschke \& Brown (1955) & $\begin{array}{l}\text { Review of placentae } \\
\text { and autopsies }\end{array}$ & $27 / 42$ & 64 & $\begin{array}{l}\text { CNS } \\
\text { Cardiac }\end{array}$ \\
\hline Faierman (1960) & Autopsy & $9 / 11$ & 82 & G-U \\
\hline Bourne \& Benirschke (1960) & Collected cases & $59 / 113$ & 52 & $\begin{array}{l}\text { G-I, G-U } \\
\text { G-V }\end{array}$ \\
\hline Lenosky \& Modovy (1962) & Autopsy & $3 / 12$ & 25 & $\begin{array}{l}\text { Multiple } \\
\text { anomalies }\end{array}$ \\
\hline
\end{tabular}

This group may still be important, however, because infants in this category, i.e. where both hydramnios and a single artery cord are noted, often have anomalies that are surgically correctable. Barrat \& Cottrell (1962) reported such a case in which a surgically correctable oesophageal atresia was noted. They further stated that only two of Benirschke's nineteen cases had survived, and both had had an operation for oesophageal atresia.

TABLE 2

STUDIES OF GONSEGUTIVE DELIVERIES

\begin{tabular}{|c|c|c|c|c|c|}
\hline & \multirow{2}{*}{ Total } & \multicolumn{2}{|c|}{ Two-vessel cords } & \multicolumn{2}{|c|}{ Anomalous infants } \\
\hline & & No. & $\%$ & No. & $\%$ \\
\hline $\begin{array}{l}\text { Little (1958) } \\
\text { Benirschke \& Bourne (1960) } \\
\text { Little (1961) } \\
\text { Lenosky \& Medovy (1962) } \\
\text { Lyon (1960) } \\
\text { Peckham \& Yerushalmy (1965) } \\
\text { Papadatos \& Paschos (1965) } \\
\text { Author }\end{array}$ & $\begin{array}{r}1200 \\
1500 \\
2800 \\
2500 \\
717 \\
5848 \\
7886 \\
4590\end{array}$ & $\begin{array}{r}12 \\
15 \\
21 \\
5 \\
8 \\
51 \\
32 \\
38\end{array}$ & $\begin{array}{l}1.0 \\
1.0 \\
0.75 \\
0.2 \\
1.1 \\
0.87 \\
0.4 \\
0.8\end{array}$ & $\begin{array}{r}3 \\
7 \\
10 \\
1 \\
2 \\
12 \\
10 \\
6\end{array}$ & $\begin{array}{l}25 \\
47 \\
48 \\
20 \\
25 \\
23 \\
31 \\
16\end{array}$ \\
\hline
\end{tabular}

(2) Foetal: Foetal sex and maturity have been investigated. All studies report a somewhat higher incidence of prematurity, but no additional significance is given to this finding.

Much more attention has been paid to the type of anomaly, or the organ system most commonly involved. For example, the genito-urinary tract was most often affected in the autopsy series of Faierman (1960), whereas previous 
authors had noted mostly cardiovascular or central nervous system malformations. Again these differences have been attributed to population biases. To date, all organ systems seem to be equally involved.

Absence of an umbilical artery is somewhat more common in monozygous twins. The study of Lenosky \& Medovy (1962) and those of Benirschke \& Bourne (1960) found the incidence to be in the range of 7 to $14 \%$.

One of the more interesting observations has been the association of trisomy with umbilical artery aplasia (Lewis, 1962). Lenosky \& Medovy found a single artery in the cords of three of six instances of chromosomal trisomy, exclusive of mongols. They feel that this occurrence may eventually be useful in selecting patients for chromosomal study.

(3) Placental: Most authors agree that there is a high percentage of placental abnormalities in these cases. Benirschke's figure was $39 \%$ (Benirschke \& Brown, 1955); Faierman (1960) also found a significant increase. Little (1958) seemed to question this finding, although he found a great number of velamentous insertions. He also established one very important practical pointthe incidence of a single artery was $1.3 \%$ when the specimen was taken from the placental end of the cord, $0.7 \%$ when taken from the foetal end. He studied twenty placentae and found that as the vessels spread out over the chorionic plate there was an anastomosis between the two umbilical arteries at the placental end of the cord. It is apparent that to determine the true incidence of single artery cords, observations must be made at the foetal end of the cord (Little, 1958, 1961).

\section{MATERIALS AND METHODS}

Specimens of umbilical cord were examined in all foetuses weighing more than $500 \mathrm{~g}$ delivered at The Woman's Clinic of The New York Hospital in a single year. Each segment was 3 to $5 \mathrm{~cm}$ in length, taken from the foetal end of the cord, and sent to the laboratory in $10 \%$ formalin. These were then examined grossly for the number of vessels, using a dissecting microscope. Each specimen was cut transversely two or three times to facilitate identification of vessels. At the end of the year charts of the cases where a single artery was observed were reviewed for maternal, foetal and placental factors in the same way as in the studies previously cited. Follow-up of each infant was then carried out through the physician and by contacting the parents 6 to 18 months after delivery.

The objectives of this study were: (1) to review the experience of The Woman's Clinic of The New York Hospital, and (2) to determine if routine cord examination is a practical and productive procedure.

\section{RESULTS}

There were 4808 consecutive births studied and 4590 cord specimens were submitted for examination (Table 2). Of this group, thirty-eight cords were found to have only a single artery. Of the infants in this category, five manifested malformations at birth, and one was found to be anomalous during follow-up (Table 3). In addition, there were two other cases of possible anomaly: one 
died in utero at 32 weeks, but only haemorrhage into the adrenals was noted at autopsy. There was no gross description of the heart although it was the only organ under the expected weight for a foetus of this size ( $15 \mathrm{~g}$ instead of $20 \mathrm{~g}$ ). The second infant was the product of a very difficult breech delivery, was quite depressed at birth, and has since manifested some retardation of activity.

TABLE 3

AFFECTED INFANTS ENGOUNTERED IN THIS STUDY

\begin{tabular}{|c|c|c|c|c|}
\hline Case No. & $\begin{array}{c}\text { Other foetal } \\
\text { anomalies }\end{array}$ & Placenta & $\begin{array}{l}\text { Maternal illness, } \\
\text { etc. }\end{array}$ & $\begin{array}{c}\text { Maternal age (years) } \\
\text { and parity }\end{array}$ \\
\hline 1 & $\begin{array}{l}\text { Cleft palate, } \\
\text { hydrocephalus }\end{array}$ & $\begin{array}{l}\text { Premature separa- } \\
\text { tion, large fibrin } \\
\text { clot }\end{array}$ & None & $\begin{array}{l}27 \\
\text { Para } 1\end{array}$ \\
\hline 2 & $\begin{array}{l}\text { Undescended } \\
\text { testes }\end{array}$ & Normal & $\begin{array}{l}\text { Heart murmur felt } \\
\text { to be functional }\end{array}$ & $\begin{array}{c}26 \\
\text { Para } 3\end{array}$ \\
\hline 3 & $\begin{array}{l}\text { Malrotation of gut, } \\
\text { small bowel } \\
\text { volvulus }\end{array}$ & Normal & None & $\begin{array}{c}22 \\
\text { Para } 2\end{array}$ \\
\hline 4 & Siamese twins & $\begin{array}{l}\text { White infarcts nega- } \\
\text { tive for melanoma }\end{array}$ & $\begin{array}{l}\text { Radiation for mela- } \\
\text { noma } 4 \text { years before }\end{array}$ & $\begin{array}{c}25 \\
\text { Para } 1\end{array}$ \\
\hline 5 & $\begin{array}{l}\text { Chordee, hypo- } \\
\text { spadias, bifid } \\
\text { thumb }\end{array}$ & $\begin{array}{l}\text { Velamentous inser- } \\
\text { tion of cord, white } \\
\text { infarcts, weight } \\
220 \mathrm{~g}\end{array}$ & Severe pre-eclampsia & $\begin{array}{c}25 \\
\text { Para } 1\end{array}$ \\
\hline 6 & $\begin{array}{l}\text { Patent ductus } \\
\text { arterious }\end{array}$ & $\begin{array}{l}\text { Retained, requiring } \\
\text { difficult manual } \\
\text { removal }\end{array}$ & None & $\begin{array}{c}25 \\
\text { Para } 3\end{array}$ \\
\hline
\end{tabular}

Table 4 lists the additional findings as suggested in previous studies. Seven mothers $(18 \%)$ exhibited some medical disorder: epilepsy, diabetes, thyrotoxicosis, inactive tuberculosis, malignant melanoma and two cases of preeclampsia. The patient with melanoma had had irradiation several years before this pregnancy; hydramnios developed and she was delivered of conjoined

TABLE 4

ASSOCIATED FACTORS

\begin{tabular}{|c|c|c|}
\hline Maternal & $\begin{array}{l}\text { Disease } \\
\text { Parity } \\
\text { Age }\end{array}$ & $\begin{array}{l}7 \quad(18 \%) \\
2 \cdot 4 \\
26 \cdot 6 \text { years }\end{array}$ \\
\hline Foetal & $\begin{array}{l}\text { Sex } \\
\text { Premature }\end{array}$ & $\begin{array}{l}26 \text { females }(68 \%) \\
8(21 \%)\end{array}$ \\
\hline Placental & Abnormalities & $13(34 \%)$ \\
\hline
\end{tabular}

twins possessing a single cord. One patient with severe pre-eclampsia delivered an $1100 \mathrm{~g}$ infant with severe chordee of the penis, hypospadias and a bifid thumb. The patient with thyrotoxicosis was treated with $11.52 \mathrm{mc}$ of radioactive iodine in the first trimester before the pregnancy was recognized. The placenta was extensively infarcted but the infant was normal. 
Prematurity existed in $21 \%$ of these cases as compared to $8 \%$ for the group as a whole. This observation had also been made previously.

Thirty-four per cent of the placentae were found to be grossly abnormal. These abnormalities included three retained placentae requiring manual removal; two with premature separation plus old infarcts; two with old infarcts alone; two with succenturiate lobes; and one each with low lying position, velamentous insertion, placental cysts and abnormally small size.

\section{DISCUSSION}

Many authors have urged the addition of umbilical cord examination to the long list of ante-partum and intra-partum routines. Some suggest that when a single artery cord is encountered, the infant should undergo further examination even if asymptomatic. Cord examination would then assume the importance of a screening test. Table 5 lists most of our routine tests, and it is noted that cord study compares rather favourably with these. However, if additional studies are to be undertaken solely on the basis of this finding, what tests should be done?

TABLE 5

ANTE-PARTUM AND INTRA-PARTUM SCREENING TESTS AT THE WOMAN'S GLINIC OF THE NEW YORK HOSPITAL

\begin{tabular}{l|c|c|c}
\hline \multirow{2}{*}{ Test } & \multirow{2}{*}{ No. of tests } & \multicolumn{2}{c}{ Positive tests } \\
\cline { 2 - 4 } & & No. & $\%$ \\
\hline Chest X-ray & 3512 & 140 & 4 \\
Indirect Coombs & 4768 & 75 & 1.5 \\
Pap. smears* & 2688 & 19 & 0.74 \\
Serologies & 4768 & 31 & 0.65 \\
Cord direct Coombs & 4808 & 155 & 3.2 \\
Cords with single arteries & 4590 & 38 & 0.83 \\
\hline
\end{tabular}

* Routine on ward patients.

Since it has been clearly shown that any organ system may be affected, and that most infants are asymptomatic, the paediatrician may be hard-pressed to outline an approach to these cases.

The figures of this study tend to coincide with those of previous authors. Sixteen per cent of the babies were anomalous as compared with $8.6 \%$ in all births. The two-fold increase is somewhat less important when it is realized that all but one of the malformations were obvious at birth or in the first few days of life. To state the results in a rather discouraging way: of 4808 births, 4590 cords were examined and thirty-eight instances of a single artery were noted; of these thirty-eight infants, six manifested anomalies, and in five the malformation was obvious at birth. The sixth baby was eventually found to have a patent ductus arteriosus.

That most malformations are obvious without the cord being studied has also been noted in previous prospective studies. Benirschke \& Bourne (1960) cited only one infant which was clinically well at birth and was later found to have an anomaly (oesophageal atresia). Little (1961) also found only one and 
Lyon (1960), and later Lenosky \& Medovy (1962), found none. The types of deformities in Peckham \& Yerushalmy's (1965) series suggest that only one may not have been obvious at birth, and possibly three in the study of Papadatos \& Paschos (1965). Add the present study to this group and the total of 27,041 consecutive deliveries produced seven infants with anomalies which were not clinically apparent at birth.

The study of Feingold, Fine \& Ingall (1964) is unique in that intravenous pyelograms were performed on twenty-four of thirty-three infants who had a single umbilical artery at birth. Among these, eight were found to have urinary tract abnormalities. This very convincing evidence may be the only type which will eventually establish the true significance of umbilical artery aplasia. Methods of studying other organ systems would also have to be evaluated.

There are definite reservations about our study, and foremost among these is the quality of follow-up. No routine tests were performed on asymptomatic infants, and follow-up data were unobtainable in five cases. It is perfectly possible for any of the 'normal' thirty-two infants to have a malformation. Also it cannot be expected that all cords will reach the laboratory, and it would seem that in complicated cases (e.g. foetal distress, emergency Caesarian section) a cord sample may be overlooked. This shortcoming probably could be eliminated, but in this study 218 specimens were not collected.

It is obvious that the drawbacks all tend to minimize the correlation between the absent umbilical artery and congenital anomalies. With these reservations fully acknowledged, it is considered appropriate to make the following conclusions: (1) The results of a review of The New York Hospital's experience in routine umbilical cord examination tend to agree with the work of previous authors: of 4590 cord specimens, thirty-eight possessed a single artery, and six infants in this group had malformations.

(2) It is not recommended that the procedure of microscopic examination of cord specimens be established as a screening test with routine follow-up on asymptomatic infants. The large number of defects at birth and the few anomalies discovered in the remaining group do not justify the great amount of laboratory work done by this and other authors.

(3) It is recommended that a single artery umbilical cord be recorded in the delivery room as any other abnormal physical finding would be, and that followup be individualized on the basis of other findings.

\section{REFERENCES}

Barrat, J. \& Cottrell, M. (1962) Apropos of the absence of an umbilical artery. Presse méd. 70, 1216. Benirschke, K. \& Bourne, G. (1960) The incidence and prognostic implication of congenital absence of one umbilical artery. Am. F. Obstet. Gynec. 79, 251.

Benirschke, K. \& Brown, W. (1955) The absence of one umbilical artery in the umbilical cords of normal and abnormal fetuses. Obstet. Gynec. 6, 399.

Bourne, G. \& Benirschke, K. (1960) Absent umbilical artery. Archs Dis. Childh. 35, 534.

Faierman, E. (1960) Significance of one umbilical artery. Archs Dis. Childh. 35, 285.

Feingold, M., Fine, R. \& INGall, D. (1964) Intravenous pyelography in infants with single umbilical artery. New Engl. F. Med. 270, 1178.

Lenosky, E. \& Medovy, H. (1962) Single umbilical artery: incidence, clinical significance, and relation to autosomal trisomy. Can. med. Ass. F. 87, 1229.

Lewis, A. (1962) Autosomal trisomy. Lancet, i, 866. 
Litrle, W. (1958) Aplasia of the umbilical artery. Bull. Sloane Hosp. Women, 4, 127.

LitTLe, W. (1961) Umbilical artery aplasia. Obstet. Gynec. 17, 695.

Lyon, F. (1960) Fetal abnormalities associated with umbilical cords containing one umbilical artery and one umbilical vein. Obstet. Gynec. 16, 716.

Papadatos, C. \& Paschos, A. (1965) Single umbilical artery and congenital malformations. Obstet. Gynec. 26, 367.

Peckham, C. \& Yerushalmy, J. (1965) Aplasia of one umbilical artery: Incidence by race and certain obstetrical factors. Obstet. Gynec. 26, 359. 